\title{
The effect of tiotropium therapy on markers of elastin degradation in COPD
}

\author{
Shuren Ma, Yong Y Lin, Lori Tartell and Gerard M Turino*
}

Address: James P. Mara Center for Lung Disease, St. Luke's-Roosevelt Hospital Center, 1000 Tenth Avenue, New York, NY 10019, USA

Email: Shuren Ma - sm2202@columbia.edu; Yong Y Lin - yylin@chpnet.org; Lori Tartell - ltartell@chpnet.org;

Gerard M Turino* - gmt1@columbia.edu

* Corresponding author

Published: 25 February 2009

Respiratory Research 2009, 10:12 doi:10.1 186/1465-9921-10-12

This article is available from: http://respiratory-research.com/content/I0/I/I2

(c) 2009 Ma et al; licensee BioMed Central Ltd.

This is an Open Access article distributed under the terms of the Creative Commons Attribution License (http://creativecommons.org/licenses/by/2.0), which permits unrestricted use, distribution, and reproduction in any medium, provided the original work is properly cited.
Received: 19 September 2008

Accepted: 25 February 2009

\begin{abstract}
Background: Desmosine and Isodesmosine (D/l) are cross-linking amino acids which are present only in mature elastin. Changes in their concentration in body fluids indicate changes in elastin degradation and can be a reflection of tissue elastase activity. This study was undertaken to determine whether continuous therapy with the long-acting bronchodilator Tiotropium bromide (TTP) could result in reductions in D/l as measured by mass spectrometry in plasma, urine and sputum.
\end{abstract}

Methods: Twelve not currently smoking patients with chronic obstructive pulmonary disease (COPD), never on TTP, were selected for study. Levels of D/l, along with measurements of FVC, $\mathrm{FEV}_{1}$ and $\mathrm{FEV} / \mathrm{FVC}$. were determined before starting TTP daily, and then one and two months after.

Results: $D / /$ decreased in plasma ( 10 of $I 2$ patients), in sputum all ( 12 of $I 2$ ), and in the percentage of free $\mathrm{D} / \mathrm{I}$ in urine (10 of I2). Most patients showed slight increases in FVC and FEV, percent predicted over two months.

Conclusion: The results are consistent with an effect of prolonged bronchodilitation by anticholinergic blockade to also result in reduced lung elastin degradation.

\section{Background}

In chronic obstructive pulmonary disease (COPD) tissue elastin injury[1] and depletion[2] have been demonstrated in lung parenchyma. Recently, techniques for detecting and quantifying elastin degradation in body fluids have advanced in specificity, sensitivity and accuracy by the use of mass spectrometry[3]. Desmosine and Isodesmosine $(\mathrm{D} / \mathrm{I})$ are cross-linking amino acids which are present only in mature elastin so that changes in their concentration in body fluids are a reflection of elastin degradation and would therefore not be a measure of elastin synthesis from precursors[4]. The use of these analytical techniques has resulted in the demonstration that patients with COPD related to smoking or the inherited deficiency of alpha-1 antitrypsin (AATD) have elevated levels of D/I in blood plasma, sputum and as a free unconjugated component in urine[5].

The use of these markers of lung elastin degradation in disease offers the prospect of evaluating levels of $\mathrm{D} / \mathrm{I}$ as indicators of possible efficacy of therapeutic interventions. 
The long acting bronchodilator TTP has been shown to reduce hospitalizations and the frequency of exacerbations in large patient populations of COPD [6-8]. TTP has also been shown to reduce the level of lung hyperinflation in COPD[9]. Previous studies have suggested that blocking acetylcholine may have effects on inflammatory mediators and smooth muscle growth factors. Such effects may be reflected in lung matrix injury with respect to elastin degradation $[10,11]$. This study examines that possibility in 12 patients with COPD studied over a 2-month interval prior to the initiation of TTP therapy and continuing daily TTP for a period of 2 months. The results indicate significant reductions in $\mathrm{D} / \mathrm{I}$ in the majority of patients so treated.

\section{Materials and methods}

Preparation of specimens of urine, plasma and sputum by liquid chromatography (LC), mass spectrometry (MS) has been described previously[2,5]. Analysis of urine utilized aliquots from 24-hour urine collections in each patient. Each sample of plasma, urine and sputum was analyzed in triplicate and their mean values and standard deviations calculated. All standard deviations are below $\pm 10 \%$.

Twelve patients with clinically stable COPD were selected for study. All patients had physiologic evidence of airway obstruction. Eleven had a history of smoking for at least 10 years but were not smoking at the time of the study and had stopped smoking over 5 years before the study. One patient with alpha-1 antitrypsin deficiency had never smoked. Two patients had homozygous- $Z$ phenotype alpha-one antitrypsin deficiency (ATTD). Patients were categorized as GOLD stages 2 and 3[12]. None of the patients had been administered TTP prior to the beginning of the study. Patients remained on their existing medical regimens. None were on oxygen or were undergoing a rehabilitation program. If they were taking any anticholinergic bronchodilators prior to the study, that medication was stopped when TTP therapy began. $18 \mu \mathrm{g}$ of TTP was administered every 24 hours. No patient had the addition or deletion of steroid inhalants during the 2month period of study.

Spirometric indices were $\mathrm{FEV}_{1}, \mathrm{FEV}_{1} / \mathrm{FVC}$ and FVC, measured prior to and after 1 and 2 months of therapy. D and I in urine, plasma and sputum were measured by LC/MS prior to the study and at 1 month and 2 months after the beginning of the study. Statistical analysis was carried out by two-tailed T test (Graph Pad Prism 4 software) $\mathrm{p}<.05$ statistical significance.

\section{Results}

Decreases in D/I levels were observed in the free componend of urine (10 of 12 patients), in plasma (10 of 12) and in sputum (all 12 patients) which is consistent with reductions in mature elastin degradation following the initiation of tiotropium therapy (see Table 2 and Figure 1 ). The percent reductions in D/I shown in Fig. 1 were calculated for each patient as the ratio derived from the difference between the pre-treatment levels of $\mathrm{D} / \mathrm{I}$ and the levels at month 2 divided by the pre-treatment level and expressed as percent reduction at 2 months. The calculated percent decreases in D/I levels after TTP treatment showed the decreases beginning after one month, with further decreases in the second month. These reductions at 2 months averaged 15\% (range 9-38\%) in urine; $27 \%$ (range 2-65\%) in plasma and 58\% (range 4-98\%) in sputum. Mean reductions in each body fluid for the 12 patients were statistically significant at $\mathrm{p}<.005$.

Tables 1, 2 and 3 show the mean values and standard deviations for all 12 patients for levels of $\mathrm{D} / \mathrm{I}$ at base line and after 2 months of tiotropium therapy and the statistical significance for the changes in urine, plasma and sputum. A paired T-test was used to test the null hypothesis that the mean value at baseline for all 12 patients was equal to the mean value at 2 months for all 12 patients. Separate analysis was performed for urine, plasma and sputum. The accepted level of significance was equal to .05 .

After 2 months of treatment, larger decreases in D/I levels were observed in sputum and plasma than in urine. The response is not always uniform in urine, plasma and sputum. Two patients (\#3 and \#5) failed to show decreases in urine but showed decreases in their plasma and sputum and another two patients (\#1 and \#6) not decreasing in plasma showed decreases in urine and sputum (see figure 1).

Overall results indicate that all 12 COPD patients responded to prolonged TTP treatment with some decrease in lung elastin degradation as measured in one of the body fluids analyzed.

Spirometrically, most patients showed slight increases in FVC and $\mathrm{FEV}_{1}$ percent predicted with usually little change in the $\mathrm{FEV}_{1} / \mathrm{FVC}$ ratio (see Table 1 ).

\section{Discussion}

$\mathrm{D} /$ I measured by mass spectrometry has the advantage of identifying and quantifying these cross-linking amino acids of elastin which are present only in mature elastin and not present in the elastin precursor tropoelastin. As such, the levels of D/I in plasma, urine and sputum are reflecting mature elastin breakdown. Since mature elastin cleavage requires the activity of specific elastases, reductions in levels of D/I in body fluids most probably are reflecting decreases in the specific activity or the concentrations of elastases in the tissue milieu. The prominent 


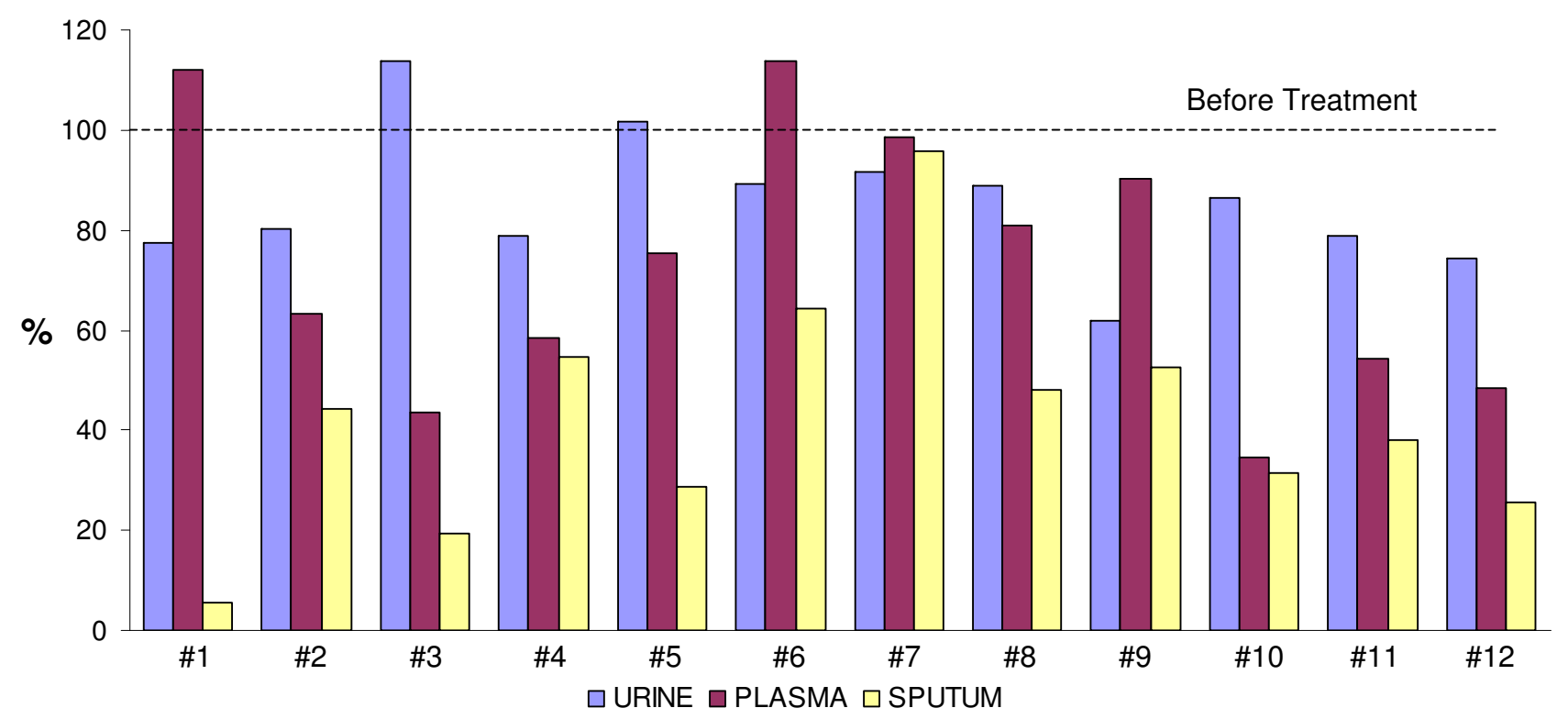

Figure I

Shown are the percentages reduction in the summed levels of Desmosine and Isodesmosine in 24-hour urine, plasma and sputum for each of $\mathbf{2}$ patients after 2-months of Tiotropium administration. The dotted line represents the pre-administration level for each patient.

tissue elastases which have been identified in bronchi and parenchyma of the lung are neutrophil elastase[13] and metalloproteases[14], of which metalloproteases 1[15], $2[16], 8,9[17-19]$ have been identified in COPD. The decreases of $\mathrm{D} / \mathrm{I}$ in urine, plasma and sputum in the majority of patients in this study after initiating long-acting anticholinergic therapy is consistent with reduction in elastase activity.

It has been our premise that the content of free (unconjugated) D/I occurs as a result of elastase activity in neutrophils and macrophages in blood and tissues, which can degrade elastin fragments prior to excretion in urine and therefore may be an indication of stimulation of neutrophils and macrophages by a heightened inflammatory state of patients with COPD as indicated by increased inflammatory markers detected in COPD $[20,21]$. The reduction in the free total excretion ratio of $\mathrm{D} / \mathrm{I}$ with Tiotropium therapy would be consistent with an anti-inflammatory effect of the therapy. This anti-inflammatory effect could occur from several mechanisms.

Improved clearance of bronchial secretions could occur consistently with decreased airway obstruction, which could reduce bacterial colonization with reductions in virulence and bacterial species.
Reducing airway obstruction and the state of lung hyperinflation may have a beneficial effect through a reduction in tissue stretch. Prior work has suggested that mechanical forces in the airways and surrounding alveolar structures may impose cellular and cytokine responses that are proinflammatory and stimulate bronchial smooth muscle reactivity $[22,23]$. In support of this concept, pro-inflammatory cytokines are increased in ventilator-induced lung injury and may be elevated in distended lung tissue[24]. Also, it has been shown that cycling mechanical stretch can profoundly affect gene expression $[22,23]$.

TTP, which blocks acetylcholine receptors has been demonstrated to inhibit allergin-induced airway remodeling in a Guinea pig model of ongoing asthma[10]. Thus, endogenous acetylcholine may be an important mediator in airway smooth muscle remodeling in asthma, a process which also has involved chronic inflammatory stimuli[11]. It is worthy of consideration that such mechanisms involving the role of acetylcholine could be involved in COPD as well as asthma and that blocking acetylcholine activity might have anti-inflammatory effects.

Additional studies have been reported which show that tiotropium can inhibit allergen-induced airway remode- 
Table I: Age, Gender, Race and Pulmonary Function of study patients

\begin{tabular}{|c|c|c|c|c|c|c|c|}
\hline PATIENT NUMBER & AGE & GENDER & RACE & STUDY & $\begin{array}{l}\text { FVC** } \\
\text { \%Pred }\end{array}$ & $\begin{array}{l}\text { FEV }{ }^{* *} \\
\text { \%Pred }\end{array}$ & $\begin{array}{c}\text { FEV }_{\mathbf{I}} / \mathbf{F V C} * * \\
\%\end{array}$ \\
\hline$-1-$ & 61 & M & $C^{*}$ & $\begin{array}{l}\text { Pre-Tio } \\
\text { I mo post } \\
2 \text { mo post }\end{array}$ & $\begin{array}{l}77 \\
91 \\
77\end{array}$ & $\begin{array}{l}47 \\
53 \\
47\end{array}$ & $\begin{array}{l}46 \\
44 \\
46\end{array}$ \\
\hline$-2-$ & 79 & $\mathrm{~F}$ & $C^{*}$ & $\begin{array}{l}\text { Pre-Tio } \\
\text { I mo post } \\
2 \text { mo post }\end{array}$ & $\begin{array}{c}97 \\
96 \\
106\end{array}$ & $\begin{array}{l}64 \\
72 \\
73\end{array}$ & $\begin{array}{l}49 \\
56 \\
51\end{array}$ \\
\hline$-3-$ & 65 & $\mathrm{~F}$ & $\mathrm{AA}^{*}$ & $\begin{array}{l}\text { Pre-Tio } \\
\text { I mo post } \\
2 \text { mo post }\end{array}$ & $\begin{array}{c}106 \\
96 \\
108\end{array}$ & $\begin{array}{l}74 \\
65 \\
66\end{array}$ & $\begin{array}{l}54 \\
53 \\
48\end{array}$ \\
\hline$-4-$ & 63 & $\mathrm{~F}$ & $C^{*}$ & $\begin{array}{l}\text { Pre-Tio } \\
\text { I mo post } \\
2 \text { mo post }\end{array}$ & $\begin{array}{l}92 \\
107 \\
100\end{array}$ & $\begin{array}{l}41 \\
52 \\
45\end{array}$ & $\begin{array}{l}46 \\
48 \\
46\end{array}$ \\
\hline$-5-$ & 65 & $\mathrm{~F}$ & $\mathrm{H}^{*}$ & $\begin{array}{l}\text { Pre-Tio } \\
\text { I mo post } \\
2 \text { mo post }\end{array}$ & $\begin{array}{l}70 \\
84 \\
84\end{array}$ & $\begin{array}{l}67 \\
84 \\
82\end{array}$ & $\begin{array}{l}75 \\
79 \\
78\end{array}$ \\
\hline$-6-$ & 65 & M & $A^{*}$ & $\begin{array}{l}\text { Pre-Tio } \\
\text { I mo post } \\
2 \text { mo post }\end{array}$ & $\begin{array}{l}56 \\
49 \\
51\end{array}$ & $\begin{array}{l}49 \\
49 \\
52\end{array}$ & $\begin{array}{l}66 \\
75 \\
78\end{array}$ \\
\hline$-7-$ & 64 & M & $C^{*}$ & $\begin{array}{l}\text { Pre-Tio } \\
\text { I mo post } \\
2 \text { mo post }\end{array}$ & $\begin{array}{l}59 \\
69 \\
64\end{array}$ & $\begin{array}{l}41 \\
47 \\
41\end{array}$ & $\begin{array}{l}51 \\
51 \\
48\end{array}$ \\
\hline$-8-$ & 39 & M & $C^{*}$ & $\begin{array}{l}\text { Pre-Tio } \\
\text { I mo post } \\
2 \text { mo post }\end{array}$ & $\begin{array}{l}52 \\
69 \\
62\end{array}$ & $\begin{array}{l}24 \\
30 \\
29\end{array}$ & $\begin{array}{l}30 \\
35 \\
38\end{array}$ \\
\hline$-9-$ & 57 & $\mathrm{~F}$ & $\mathrm{H}^{*}$ & $\begin{array}{l}\text { Pre-Tio } \\
\text { I mo post } \\
2 \text { mo post }\end{array}$ & $\begin{array}{l}93 \\
87 \\
83\end{array}$ & $\begin{array}{l}55 \\
55 \\
53\end{array}$ & $\begin{array}{l}47 \\
51 \\
51\end{array}$ \\
\hline$-10-$ & 69 & M & $\mathrm{AA}^{*}$ & $\begin{array}{l}\text { Pre-Tio } \\
\text { I mo post } \\
2 \text { mo post }\end{array}$ & $\begin{array}{c}58 \\
82 \\
109\end{array}$ & $\begin{array}{l}30 \\
39 \\
54\end{array}$ & $\begin{array}{l}39 \\
36 \\
38\end{array}$ \\
\hline$-11-$ & 66 & $\mathrm{~F}$ & $C^{*}$ & $\begin{array}{l}\text { Pre-Tio } \\
\text { I mo post } \\
2 \text { mo post }\end{array}$ & $\begin{array}{c}97 \\
103 \\
90\end{array}$ & $\begin{array}{l}62 \\
60 \\
58\end{array}$ & $\begin{array}{l}49 \\
45 \\
48\end{array}$ \\
\hline$-12-$ & 59 & M & $C^{*}$ & $\begin{array}{l}\text { Pre-Tio } \\
\text { I mo post } \\
2 \text { mo post }\end{array}$ & $\begin{array}{l}110 \\
91 \\
102\end{array}$ & $\begin{array}{l}72 \\
69 \\
71\end{array}$ & $\begin{array}{l}50 \\
57 \\
53\end{array}$ \\
\hline
\end{tabular}

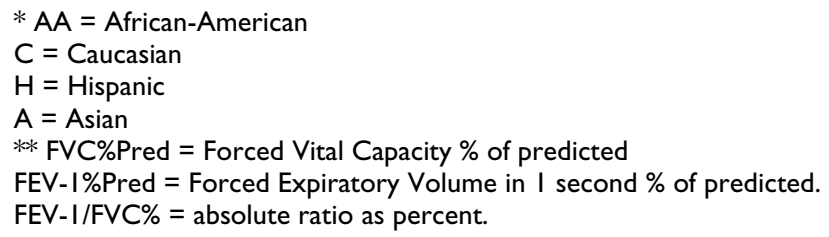

ling in a Guinea pig model of allergic asthma[25]. Also, tiotropium has been shown to suppress acetylcholineinduced release of chemotactic mediators in vitro in neu- trophils and macrophages and specifically LTB4[26]. However, measurements of sputum and serum markers of inflammation such as CRP and IL-6 have not been 
Table 2: Effect of Tiotropium treatment on levels of desmosine and Isodesmosine

\begin{tabular}{|c|c|c|c|c|c|}
\hline \multicolumn{2}{|c|}{ PATIENTS } & \multicolumn{2}{|c|}{$\frac{\text { URINE }}{\text { (ug/g creatinine) }}$} & \multirow{2}{*}{$\frac{\text { PLASMA }}{(\mathrm{ng} / \mathrm{ml})}$} & \multirow{2}{*}{$\frac{\text { SPUTUM }}{(\mathrm{ng} / \mathrm{ml})}$} \\
\hline & & FREE & F/T(\%) & & \\
\hline \multirow[t]{3}{*}{$-1-$} & 0 month & 6.57 & 49.6 & 0.42 & 0.92 \\
\hline & I month & 4.99 & 48.5 & 0.37 & 0.15 \\
\hline & 2 month & 5.29 & 38.5 & 0.47 & 0.05 \\
\hline \multirow[t]{3}{*}{$-2-$} & 0 month & 9.50 & 40.8 & 0.71 & 0.77 \\
\hline & I month & 5.91 & 41.9 & 0.67 & 0.19 \\
\hline & 2 month & 7.50 & 32.7 & 0.45 & 0.33 \\
\hline \multirow[t]{3}{*}{$-3-$} & 0 month & 3.90 & 35.1 & 0.71 & 0.52 \\
\hline & I month & 5.37 & 38.1 & 0.54 & 0.26 \\
\hline & 2 month & 4.45 & 39.9 & 0.33 & 0.10 \\
\hline \multirow[t]{3}{*}{$-4-$} & 0 month & 5.14 & 45.0 & 0.77 & 0.33 \\
\hline & I month & 4.82 & 42.3 & 0.40 & 0.23 \\
\hline & 2 month & 6.91 & 32.5 & 0.45 & 0.18 \\
\hline \multirow[t]{3}{*}{$-5-$} & 0 month & 7.54 & 46.2 & 0.73 & 0.49 \\
\hline & I month & 4.95 & 51.4 & 0.57 & 0.16 \\
\hline & 2 month & 4.68 & 47.1 & 0.55 & 0.14 \\
\hline \multirow[t]{3}{*}{$-6-$} & 0 month & 3.31 & 36.2 & 0.44 & 0.05 \\
\hline & I month & 3.72 & 34.2 & 0.40 & 0.01 \\
\hline & 2 month & 3.05 & 31.4 & 0.50 & 0.03 \\
\hline \multirow[t]{3}{*}{$-7-$} & 0 month & 3.40 & 40.9 & 0.62 & 0.23 \\
\hline & I month & 5.38 & 40.2 & 0.63 & 0.30 \\
\hline & 2 month & 4.79 & 37.4 & 0.61 & 0.22 \\
\hline \multirow[t]{3}{*}{$-8-$} & 0 month & 3.76 & 39.4 & 0.52 & 0.27 \\
\hline & I month & 3.48 & 35.3 & 0.39 & 0.29 \\
\hline & 2 month & 3.15 & 35.0 & 0.42 & 0.13 \\
\hline \multirow[t]{3}{*}{$-9-$} & 0 month & 6.61 & 63.2 & 0.51 & 0.19 \\
\hline & I month & 5.26 & 43.0 & 0.64 & 0.22 \\
\hline & 2 month & 4.71 & 39.1 & 0.46 & 0.10 \\
\hline \multirow[t]{3}{*}{-10} & 0 month & 7.59 & 50.7 & 0.75 & 0.19 \\
\hline & I month & 5.98 & 46.6 & 0.46 & 0.12 \\
\hline & 2 month & 4.87 & 43.9 & 0.26 & 0.06 \\
\hline \multirow[t]{3}{*}{$-11-$} & 0 month & 5.67 & 51.0 & 0.61 & 0.22 \\
\hline & I month & 4.71 & 45.3 & 0.38 & 0.08 \\
\hline & 2 month & 4.97 & 40.2 & 0.33 & 0.08 \\
\hline \multirow[t]{3}{*}{$-12-$} & 0 month & 5.83 & 53.4 & 0.67 & 0.52 \\
\hline & I month & 5.13 & 48.9 & 0.34 & 1.07 \\
\hline & 2 month & 5.55 & 39.7 & 0.33 & 0.13 \\
\hline \multicolumn{2}{|c|}{$\frac{\text { Normal Subjects }[5]}{(\mathrm{n}-13)}$} & $\underline{2.52}( \pm 0.53)$ & $\frac{19.0}{( \pm 2.0)}$ & $\left(=\frac{0.19}{+0,01)}\right.$ & none \\
\hline
\end{tabular}

reduced in patients with COPD treated for 12 months with tiotropium[27]. Further study of TTP and other inflammatory markers in COPD seem warrented.
It should be noted that measurements of $(\mathrm{D} / \mathrm{I})$ in plasma and urine may be reflecting elastin degradation derived from elastin sources other than the lung per se, such as 
Table 3: Mean changes in desmosine and Isodesmoeine after two months of Tiotropium therapy

\begin{tabular}{|c|c|c|c|c|}
\hline \multirow[t]{2}{*}{ BODY FLUID } & \multirow[t]{2}{*}{$\mathbf{N}$} & \multicolumn{2}{|c|}{ LEVELS (mean \pm SD) } & \multirow[t]{2}{*}{ P VALUE } \\
\hline & & AT BASELINE & AT 2 MONTHS & \\
\hline Plasma ng/ml & 12 & $0.62 \pm 0.12$ & $0.43 \pm 0.10$ & 0.0037 \\
\hline Urine (free/total \%) & 12 & $45.96 \pm 8.11$ & $38.37 \pm 4.43$ & 0.0044 \\
\hline Sputum ng/ml & 12 & $0.39 \pm 0.26$ & $0.13 \pm 0.02$ & 0.0035 \\
\hline
\end{tabular}

blood vessels or skin. D/I in sputum, however, should be reflecting only elastin degradation from lung tissue and therefore may be the most sensitive index of a therapeutic effect[28]. Also, the presence of D/I in sputum is an indictor that lung elastin is in flux, although the contribution to plasma or urinary levels from that source cannot be determined. In this regard, induced sputum from normal subjects has no detectable D/I[3].

This anti-inflammatory response to TTP, as demonstrated by measurements of $\mathrm{D} / \mathrm{I}$ are consistent with the preliminary result of a reduction in $\mathrm{FEV}_{1}$ loss at the end of one year of follow-up in patients receiving TTP therapy[29]. Also, the results of this study are consistent with the previously reported reductions in COPD exacerbations and required hospitalizations in large cohorts of COPD patients [6-8].

The pre-TTP treatment levels of D/I were established with single measurements in plasma, urine and sputum in each patient. This may be of concern since fluctuations of single measurements in an individual might effect the final results. In this regard, prior data has been published from our laboratory [5] concerning the variation of repeat measurements in plasma in single individuals in a stable clinical state over days, weeks and months. The variability was maximally $15 \%$. The results of the present study demonstrated consistent reductions in levels of $\mathrm{D}$ and $\mathrm{I}$ in plasma, urine and sputum which result is unlikely to be reflecting fluctuations in the measurements during a stable clinical state. Also, a recent study[30] in patients with AATD demonstrated increases in urinary desmosine at six months and 1 year and no decreases.

There were no clinical or spirometric characteristics which distinguished those patients who had the most marked reduction in D/I from those less responsive. Lack of correlation of $\mathrm{D} / \mathrm{I}$ excretory patterns with clinical phenotype in COPD has been previously reported[31].

Patients \#8 and \#12" had AATD. Both have quite marked reductions in the sputum levels of $\mathrm{D} / \mathrm{I}$ with modest reductions in urine and plasma.
AATD patients have been shown to have higher levels of $\mathrm{D} / \mathrm{I}$ among COPD patients in general[5]. Whether the reduction in D/I in sputum or plasma and urine could be greater in AATD patients in general must await further study. The results of this study indicate the potential application of $\mathrm{D} / \mathrm{I}$ as markers to evaluate therapeutic effects in COPD.

\section{Conclusion}

Two months of therapy by anticholinergic blockage for bronchodilitation resulted in reduction in elastin degradation in most patients with COPD, suggesting an antiinflammatory effect.

\section{Abbreviations}

COPD: Chronic Obstructive Pulmonary Disease; D/I: desmosine and isodesmosine; LC: liquid chromatography; MS: Mass Spectrometry; FVC: Forced vital capacity; $\mathrm{FEV}_{1}$ : Forced expiratory volume in one second

\section{Competing interests}

The authors declare that they have no competing interests.

\section{Authors' contributions}

SM performed liquid chromatography, mass spectronometric measurements of $\mathrm{D} / \mathrm{I}$ and statistical analysis of data; YYL assisted with preparative procedures for chemical analysis of D/I and study planning; LT supervised patients selected for study and their participation in the study, including spirometry; GMT was involved in study planning, patient selection and a creating a draft manuscript. All authors participated in manuscript design and revisions and approved the final manuscript.

\section{Acknowledgements}

This work was supported by funds from the James P. Mara Center for Lung Disease, the Flight Attendants Medical Research Institute, the Charles A. Mastronardi Foundation, the Ned Doyle Foundation, the Alpha One Foundation and funds from Ethel Kennedy, John Kennedy, Judith Sulzberger and the Boehringer-Ingelheim Corp. The authors express their deep appreciation to Dr. Seymour Lieberman for consultative advice. 


\section{References}

I. Wright RR: Elastic tissue of normal and emphysematous lungs: a tridimensional histologic study. Am J Path 1961, 39:355-367.

2. Chrzanowski P, Keller S, Cerreta J, Mandl I, Turino GM: Elastin content of normal and emphysematous lung parenchyma. Amer J Med 1980, 69:351-359.

3. Ma S, Lieberman S, Turino GM, Lin YY: The detection and quantitation of free desmosine and isodesmosine in human urine and their peptide-bound forms in sputum. PNAS 2003, | 00: | 294|- | 2943.

4. Rosenbloom J: "Biochemical/immunologic markers of emphysema" Pulmonary Emphysema: the Rational for Therapeutic Intervention. Ann NY Acad Sci 1991, 624S:7-I2.

5. Ma S, Lin YY, Turino GM: Measurements of Desmosine and Isodesmosine by Mass Spectrometry in COPD. CHEST 2007, |3 I:|363-7|.

6. Niewoehner DE, Rice K, Cote C, Paulson D, Cooper AD Jr, Korducki L, Cassino C, Kesten S: Prevention of exacerbations of chronic obstructive pulmonary disease with tiotropium, a once-daily inhaled anticholinergic bronchodilator, a randomized trial. Ann Intern Med 2005, I 43:317-26.

7. Vincken W, van Noord JA, Greefhorst APM, Bantje ThA, Kesten S, Korducki L, et al.: Improved health outcomes in patients with COPD during one year's treatment with tiotropium. Eur Respir J 2002, 19:209-16.

8. Casaburi R, Mahler DA, Jones PW, Wanner A, San Pedro G, ZuWallack RL, et al.: A long-term evaluation of one-daily tiotropium in chronic obstructive pulmonary disease. Eur Respir J 2002, 19:217-24

9. Celli B, ZuWallack R, Wang S, Kesten s: Improvement in resting inspiratory capacity and hyperinflation with tiotropium in COPD patients with increased static lung volumes. Chest 2003, I 24: 1743-48.

10. Gosen R, Bos IS, Zaagsma J, Meurs H: Protective effects of tiotropium bromide in the progression of airway smooth muscle remodeling. AJRCCM 2005, I 7 I(I 0): I096-I I 02.

II. Kanazawa $\mathrm{H}$ : Anticholinergic agents in asthma: Chronic bronchiodilator therapy, relief of acute severe asthma, reduction of chronic viral inflammation and prevention of remodeling. Curr Opin Pulm Med 2006, I 2(I):60-67.

12. Pauwels RA, Buist AS, Calverley PM, et al.: Global stragegy for diagnosis, management and prevention of chronic obstructive pulmonary disease: NHLI/WHO Global Initiative for Chronic Obstructive Lung Disease (GOLD) Workshop Summary. Am J Respir Crit Care Med 200I, I 63:I256-76.

13. Janoff $A$ : Elastases and emphysema: Current assessment of the protease-antiprotease hypothesis. Am Rev Respir Dis 1985, 132:417-33.

14. Shapiro SD: Proteinases in chronic obstructive pulmonary disease. Biochem Soc Trans 2002, 30:98-102.

15. Imai K, Dalal SS, Chen ES, Downey R, Schulman LL, Ginsburg M, D'Armiento J: Human collagenase (matrix metalloproteinaseI) expression in the lungs of patients with emphysema. $\mathrm{Am} J$ Respir Crit Care Med 200I, I 63:786-9I.

16. Baraldo S, Bazzan E, Zanin ME, Turato G, Garbisa S, Maestrelli P, Papi A, Miniati M, Fabbri L, Zuin R, Saetta M: Matrix Metalloproteinase-2 protein in lung periphery is related to COPD progression. CHEST 2007, I32:1733-40.

17. Vernooy $\mathrm{JH}$, Lindeman $\mathrm{J}$, Jacobs $\mathrm{JA}$, et al.: Increased activity of matrix metalloproteinase-8 and matrix metalloproteinase-9 in induced sputum from patients with COPD. CHEST 2004, I 26: $1082-10$.

18. Russell REK, Russell SV, Culpitt CDM, Donnelly L, Smith M, Wiggins J, Barnes PJ: Release and activity of matrix metalloproteinase9 and tissue inhibitor of metalloproteinase-I by alveolar macrophages from patients with chronic obstructive pulmonary disease. Am J Respir Cell Mol Biol 2002, 26:602-09.

19. Finlay GA, O'Driscoll LR, Russell KJ, D'Arcy EM, Masterson JB, Fitzgerald MX, O'Connor CM: Matrix metalloproteinase expression and production by alveolar macrophages in emphysema. Am J Respir Crit Care Med 1997, I 56:240-247.

20. Agusti AGN: Systemic effects of chronic obstructive pulmonary disease. Proc ATS 2005, 2:367-70.

21. Rodriguez JR, Seals JE, Radin A, et al:: Neutrophil Iysosomal elastase activity in normal subjects and in patients with chronic obstructive lung disease. Am Rev Respir Dis 1979 , I 1 9:409-I7.

22. Waters CM, Sporn PHS, Liu M, Fredberg J): EB2002 Symposium Report: Cellular biomechanics in the lung. Am J Physiol Lung Cell Mol Physiol 2002, 283:L503-L509.

23. Vlahakis NE, Schroeder MA, Limper AH, Hubmayr RD: Stretch induces cytokine release by alveolar epithelial cells in vitro. Am J Physiol Lung Cell Mol Physiol 1999, 277:LI67-LI73.

24. Ricard JD, Dreyfuss D, Saumon G: Production of inflammatory cytokines in ventilator-induced lung injury: a reappraisal. Am J Respir Crit Care Med 200 I, I63:I I76-80.

25. Bos IST, Gosens R, Zuidhof AB, Schaafsma D, Halayko AJ, Meurs H, Zaagsma J: Inhibition of allergen-induced airway remodelling by tiotropium and budesoneide: a comparison. Eur Respir J 2007, 30:653-66I.

26. Buhling F, Lieder N, Kuhlmann UsC, Waldburg N, Welte T: Tiotropium suppresses acetylcholine-induced release of chemotactic mediators in vitro. Respir Med 2007, I 0 I:2386-94.

27. Powrie DJ, Wilkinson TMA, Donaldson GC, Jones P, Scrine K, Viel K, KEsten S, edzicha JA: Effect of tiotropium on sputum and serum inflammatory markers and exacrbations in COPD. Eur Respir J 2007, 30:472-78.

28. Cantor JO: The need for real-time measurement of lung injury in developing an effective treatment for pulmonary emphysema. Curr Phar Anal 2007, 3:129-132.

29. Anzueto A, Tashkin D, Memjoge S, Kesten S: One year analysis of longitudinal changes in spectrometry in patients with COPD receiving Tiotropium. Pulm Pharma Ther 2005, I8:75-8I. (PMIDI56-49848)

30. Fregonese L, Fumagalli M, Ferrari F, Luisetti M, ladarola P, Stolk J: Long-term changes of elastin breakdown priducts in alpha-I antitrypsin deficiency (Abstract). Eur Respir J 2007: 1408.

31. Boschetto P, Quintavalle S, Zeni E, Leprotti S, Potena A, Ballerin R, Papi A, Palladini G, Luisetti M, Annovazzi L, ladarola P, DeRosa E, Fabbri LM, Mapp C: Markers of emphysema are associated with more severe chronic obstructive pulmonary disease. Thorax 2006, 6 I : 1037-42.

\section{Publish with Biomed Central and every scientist can read your work free of charge}

"BioMed Central will be the most significant development for disseminating the results of biomedical research in our lifetime. "

Sir Paul Nurse, Cancer Research UK

Your research papers will be:

- available free of charge to the entire biomedical community

- peer reviewed and published immediately upon acceptance

- cited in PubMed and archived on PubMed Central

- yours - you keep the copyright

Submit your manuscript here:

http://www.biomedcentral.com/info/publishing_adv.asp
BioMedcentral 